\title{
Effect of Mycorrhiza, Fertilizers and Planting Media on Rock Melon (Cucumis Melo Linn Cv. Glamour) Growth Using The Canopytechture Structure
}

\author{
Hamdan Mohd Noor*, Hanim Ahmad, Zulhazmi Sayuti \\ Horticulture Research Centre, Malaysian Agricultural Research and Development Institute, Serdang, Malaysia \\ Email address: \\ hamdanor@mardi.gov.my (H. M. Noor) \\ ${ }^{*}$ Corresponding author \\ To cite this article: \\ Hamdan Mohd Noor, Hanim Ahmad, Zulhazmi Sayuti. Effect of Mycorrhiza, Fertilizers and Planting Media on Rock Melon (Cucumis Melo \\ Linn Cv. Glamour) Growth Using The Canopytechture Structure. International Journal of Applied Agricultural Sciences. \\ Vol. 5, No. 1, 2019, pp. 14-19. doi: 10.11648/j.ijaas.20190501.12
}

Received: October 11, 2018; Accepted: October 26, 2018; Published: January 29, 2019

\begin{abstract}
Rock melon (Cucumis melo Linn), one of the most popular and delicious fruits of Malaysia has great potential for commercial development. Currently, rock melon is most widely cultivated under rain shelter structure using soilless culture. This study aimed to determine the effect of mycorrhiza, various fertilizer and planting media applications on growth performance of rock melon (Cucumis melo Linn cv. Glamour) in open area. The experiment comprised the following treatments: T1 $=$ Medium A - Mycorrhizal + Inorganic fertilizer, T2 = Medium A + Mycorrhiza + Organic fertilizer, T3 = Medium A + Mycorrhiza + Inorganic fertilizer, T4 $=$ Medium A - Mycorrhizal + Organic fertilizer, T5 $=$ Medium B + Mycorrhiza + Organic fertilizer, T6 = Medium B + Mycorrhiza + Inorganic fertilizer, T7 = Medium B - Mycorrhiza + Organic fertilizer and T8 = Medium B - Mycorrhiza + Inorganic fertilizer. Medium A consisted of Peat moss + Perlite + Vermiculite while Medium B comprised Peat moss + Perlite + Vermiculite + Top soil. A randomised complete block design experiment with three replications was conducted at the Horticulture Research Centre plot, MARDI, Serdang. Different types of fertilizer, planting media and applications of arbuscular mycorrhizal had effects on fruit production and yield of melon as compared to control (T1). Maximum and significant yield of melon was from T6 plants. Furthermore, the maximum fruit weight and total soluble solids of $1350 \mathrm{~g}$ and $14.25^{\circ}$ Brix, respectively, were from T6 treated plants and the minimum was from T4 (717 g and $10.17^{\circ}$ Brix, respectively). The presence of the indigenous arbuscular mycorrhizal inoculums in planting media was successful in colonizing plant roots, resulting in better plant growth and significantly enhanced yield of rock melon. This study suggested the possibility of applying moderate combinations of planting media with mycorrhiza in producing good quality and high yield of rock melon.
\end{abstract}

Keywords: Cucumis Melo L., Horticulture, Mycorrhizal Inoculums, Canopytechture Structure

\section{Introduction}

Horticultural cultivation is becoming widespread in urban areas of Malaysia. Growing climbing vegetables vertically in pots using a simple structure called Canopytechture (Figure 1) has been developed by Malaysian Agricultural Research and Development Institute (MARDI). The Canopytechture is a multi-purpose supportive support system for cultivating climbing vegetables and fruit trees. It is a specially designed structure to allow the plants to twist, cling and grow vertically. This structure has a special hexagonal shade frame measuring 150 centimeters in diameter and is located on a support pole with a height of $180 \mathrm{~cm}$. Through training and bending process, vegetables or fruit trees can grow vertically and produce fruits that hang in the special section. For urban agriculture, this simple multipurpose support structure is very practical to be applied with a self-watering container (SWC) or regular pot for cultivating climbing vegetables such as angled gourd, bitter gourd, cucumber and pumpkin as well as fruits such as grapes, passion fruit and melons. Its use can help the landowners to grow crops in limited spaces. 


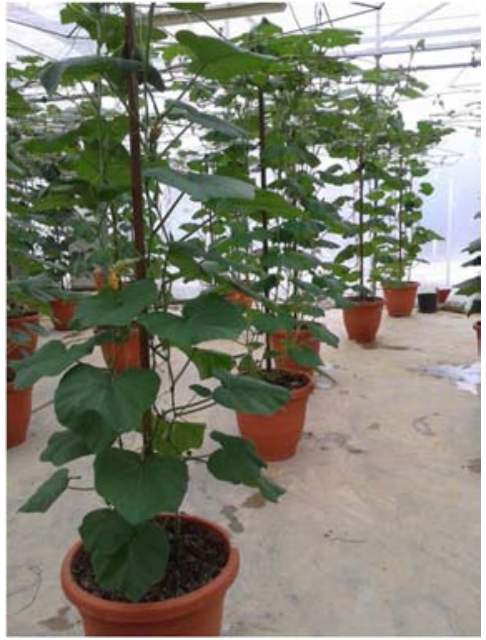

Figure 1. Canopytechture - a simple structure for climbing vegetables developed by MARDI.

In addition to crop yields, Canopytechture can also give aesthetic impact and become a therapeutic element in the site. Increased use of fertilizers can affect both human and the environment. A reduction of fertilizer input together with selecting suitable combinations of planting media will better adapt to these constrains thereby increasing the sustainability of crop production.

Arbuscular mycorrhizal fungi (AMF) can be integrated in soil management to achieve low-cost sustainable agricultural systems [1, 2]. Mycorrhizal fungi occur in most of the soils and colonize roots of many plant species. Mycorrhiza are structures resulting from the symbiosis between these fungi and plant roots, and are directly involved in plant mineral nutrition. The symbiotic root-fungal association increases the uptake of less mobile nutrients [2, 3]. AMF can also benefit plants by stimulating the production of growth regulating substances, increasing photosynthesis, improving osmotic adjustment under drought and salinity stresses and increasing resistance to pests and soil borne diseases [4]. These benefits are mainly attributed to improved phosphorous nutrition [2, 5]. Most horticultural and crop plants establish the symbiosis with AMF. Although the mycorrhizal potential of the symbiosis to improve horticultural production is recognized $[2,6]$, it has not been implemented under field conditions, integrating this biotechnology in large horticultural production systems [7]. Melon (Cucumis melo L.), a common fruit in the South East Asia region, forms the arbuscular mycorrhizal symbiosis [8], with a positive effect on plant growth [2, 7] under controlled experimental conditions.

Rock melon (Cucumis melo Linn), a common fruit in South East Asia region, forms the arbuscular mycorrhizal symbiosis [8], with a positive effect on plant growth [2] under controlled experimental conditions. Cucurbitaceae family crop responds well to an increased fertilization [2, 9] reported that the amendment of soil with vermicompost in quantities ranging from 10 to $50 \%$ significantly increased dry matter yields of cucumber plants, compared to treatments where soil was not amended. Mycorrhizal inoculation of cucumber could increase seedling quality and reduce the quantity of fertilizer application, to achieve similar yields to non-inoculated plants $[2,7,10,11]$. In this work we attempted to find a niche for the production of mycorrhizal inoculated seedling with the objective of substituting partially or completely the fruit quality and yield application with mycorrhizal inoculation. We screened different combinations of planting media with and without mycorrhiza, assessing the effects on melon seedling growth and yield under field conditions.

\section{Materials and Methods}

\subsection{Experimental Site and Growth Conditions}

The experiments were conducted in an open area located at Horticulture Research Centre plot, MARDI, Serdang Selangor $\left(2^{\circ} 59^{\prime} 51.4374^{\prime \prime} \mathrm{N} 101^{\circ} 41^{\prime} 26.227^{\prime \prime} \mathrm{E} / 2.997622^{\circ}\right.$ $\left.\mathrm{N} 101.690619^{\circ} \mathrm{E}\right)$, with average minimum/maximum temperatures of $23.0^{\circ} \mathrm{C}-33.0^{\circ} \mathrm{C}$ (Figure 2). Rock melon (Cucumis melo. L. cv. Glamour) seeds were sown in germination trays filled with peat and was placed in a growth chamber under controlled conditions for one week. At 7 to 10 days after emergence, uniform seedlings were selected and gently removed from the trays and transplanted into planting pots measuring $52 \mathrm{~cm} \mathrm{x} 46 \mathrm{~cm}$ (width $\mathrm{x}$ height) which were complete with the Canopytechture structure. Plants were manually irrigated twice a day and kept well watered for a week until plant roots were well established (Figure 3). The plants were then subjected to 8 different of treatments:

$\mathrm{T} 1=$ Medium A - Mycorrhiza + Inorganic fertilizer, T2 = Medim A + Mycorrhiza + Organic fertilizer, T3 = Medium A + Mycorrhiza + Inorganic fertilizer, T4 $=$ Medium A Mycorrhiza + Organic fertilizer, $\mathrm{T} 5=$ Medium $\mathrm{B}+$ Mycorrhiza + Organic fertilizer, T6 $=$ Medium B + Mycorrhiza + Inorganic fertilizer, $\mathrm{T} 7=$ Medium $\mathrm{B}$ Mycorrhiza + Organic fertilizer and $\mathrm{T} 8=$ Medium B Mycorrhiza + Inorganic fertilizer. Medium A consists of Peat moss + Perlite + Vermiculite (40 litres/pot - 72 pots) and Medium B consists of Peat moss + Perlite + Vermiculite + Top soil (40 litres/pot - 72 pots). Thirty grams of mixed mycorrhizal inoculums (Glomus mossae) locally obtained from University Putra Malaysia (UPM) were placed below the melon root ball at transplanting.

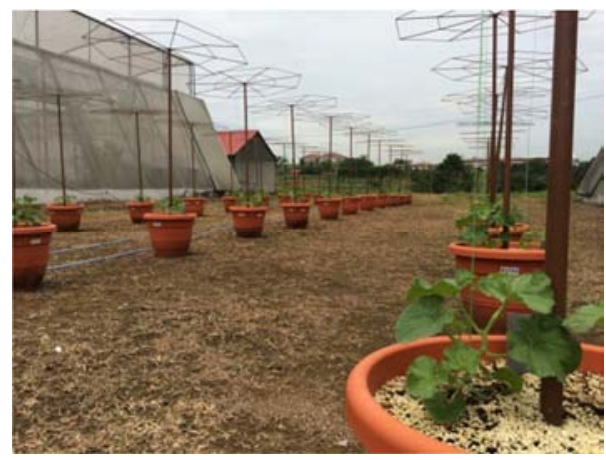

Figure 2. Canopytechture were placed at experimental site in open area. 


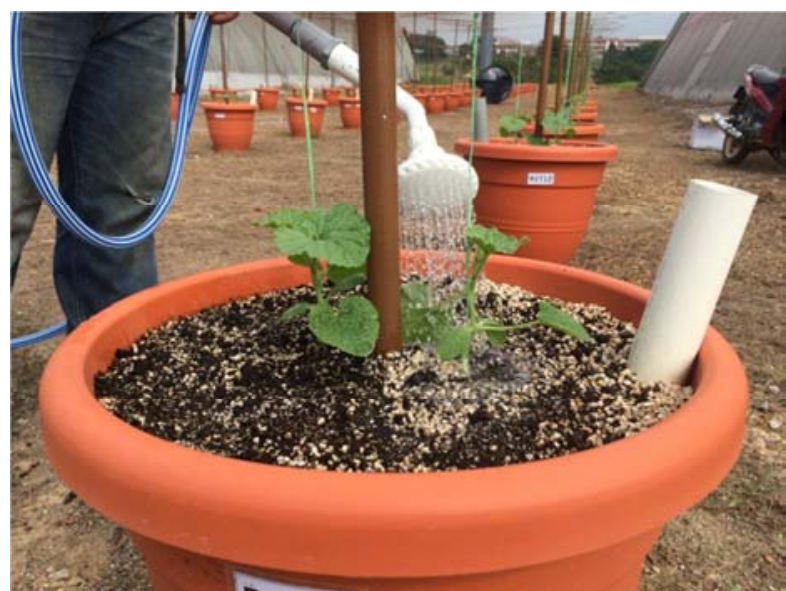

Figure 3. Rock melon plants were manually irrigated at early establishment stage.

Plants were subjected at two application of fertilizer types, organic and inorganic. The organic fertilizer was processed chicken dung at $300 \mathrm{~g} / \mathrm{plant}$, while inorganic fertilizer was NPK green and NPK blue at $50 \mathrm{~g} /$ plant. Data taken were plant height, vine length, number of leaves, number of nodes, stem diameter, fruit weight, fruit length, fruit diameter, total soluble solids, rind and flesh thickness.

\subsection{Experimental Design and Statistical Analysis}

The experimental design was a randomized complete block design (RCBD) with three replications. Analysis of variance (ANOVA) was performed using the procedures of the Statistical Analysis System [12]. The Least Significant Difference (LSD) was used for test of significance.

\subsection{Determination of Yield and Fruit Quality}

Total fruit fresh weight was recorded at the end of the growing season i.e. at 76 days after transplanting (DAT). In all treatments, only one fruit was borne per plant located between leaf number 7 to 13 or node 7 to 12 . Total soluble solids (TSS) of rock melon from respective treatments were assessed at harvest, i.e. at 76 DAT. The TSS was determined on the juice extracted from the pericarp sliced from the equatorial region of the fruit using a hand held refractometer (Model ATC-1 Atago, Tokyo, Japan), with automatic temperature compensation.

\section{Results and Discussion}

\subsection{Plant Height}

Growth performance parameters evaluated showed statistical differences in rock melon plants following applications of different types of fertilizers, planting media and mycorrhiza. At 76 DAT, the maximum and significant on plant height was recorded from T6 plants $(190.78 \mathrm{~cm})$ while the lowest plant height was recorded from T4 plants (146.89 $\mathrm{cm}$ ) at harvest (Figure 4).

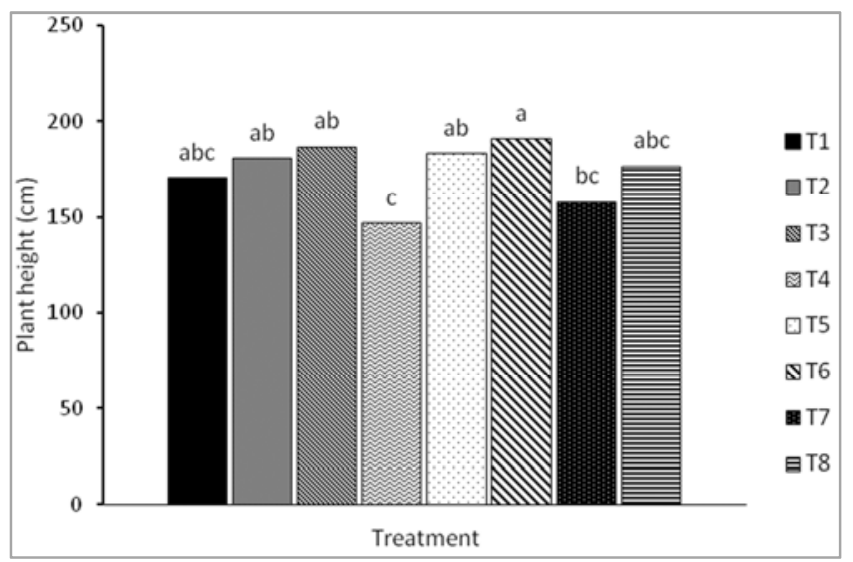

Figure 4. Effect of fertilizers, planting media and mycorrhizal inoculation treatments on plant height of rock melon using Canopytechture structure under field condition. Means followed by the same letter in figure were not different at $p \leq 0.05$ by the least significant difference (LSD) test.

\subsection{Vine Length}

Results obtained showed an increase on vine length with the similar trend according to the treatment tested. Vine length from T6 and T3 plants were 205.11 and $198.72 \mathrm{~cm}$, respectively, higher and significantly different from T4 plants $(157.61 \mathrm{~cm})$ at 76 DAT (Figure 5). However, results were not significantly different between $\mathrm{T} 1, \mathrm{~T} 2, \mathrm{~T} 5, \mathrm{~T} 7$ and $\mathrm{T} 8$ at $185.22,187.39,190.78,183.89$ and $186.71 \mathrm{~cm}$, respectively.

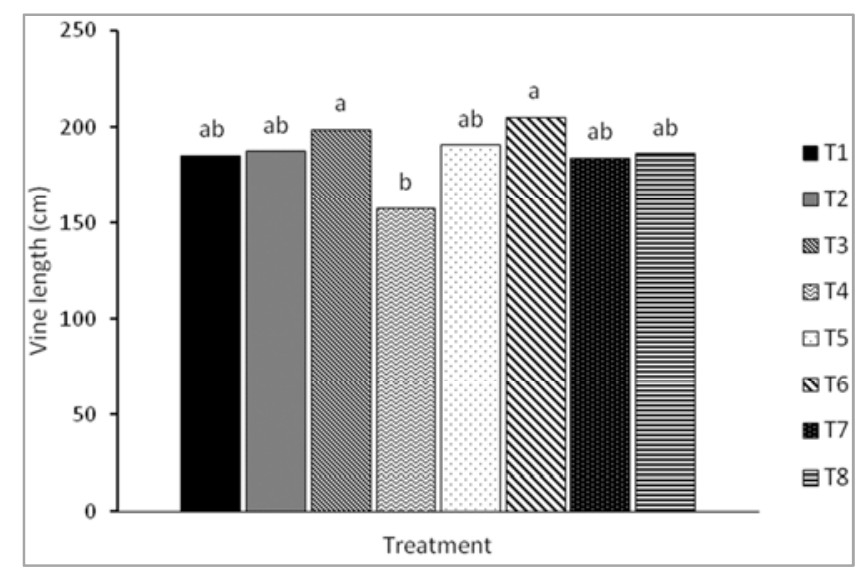

Figure 5. Effect of fertilizers, planting media and mycorrhizal inoculation treatments on vine length of rock melon using Canopytechture structure under field condition. Means followed by the same letter in figure were not different at $p \leq 0.05$ by the least significant difference (LSD) test.

\subsection{Number of Leaves}

Leaf number also showed an increase with an increase in plant growth, with maximum and significant results obtained from T6 plants (31 leaves) at harvest (76 DAT). Again T4, $\mathrm{T} 7, \mathrm{~T} 1$ and $\mathrm{T} 8$ plants showed the sequent least increase in total leaf number at harvest (Figure 6). 


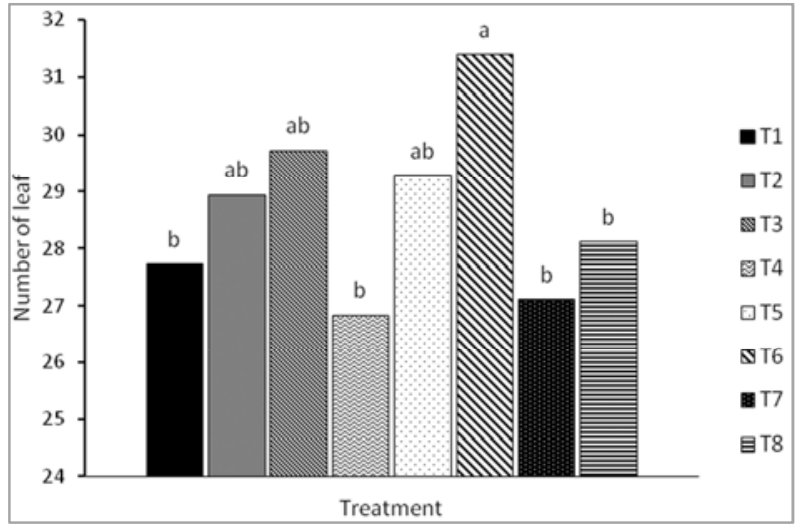

Figure 6. Effect of fertilizers, planting media and mycorrhizal inoculation treatments on number of rock melon leaf using Canopytechture structure under field condition. Means followed by the same letter in figure were not different at $p \leq 0.05$ by the least significant difference (LSD) test.

\subsection{Number of Nodes}

Number of nodes in T6 plants (30.50) was higher as compared to other treatments. Again the minimum number of node reading of 26.61 and 26.83 were from T4 and T7 plants, respectively (Figure 7).

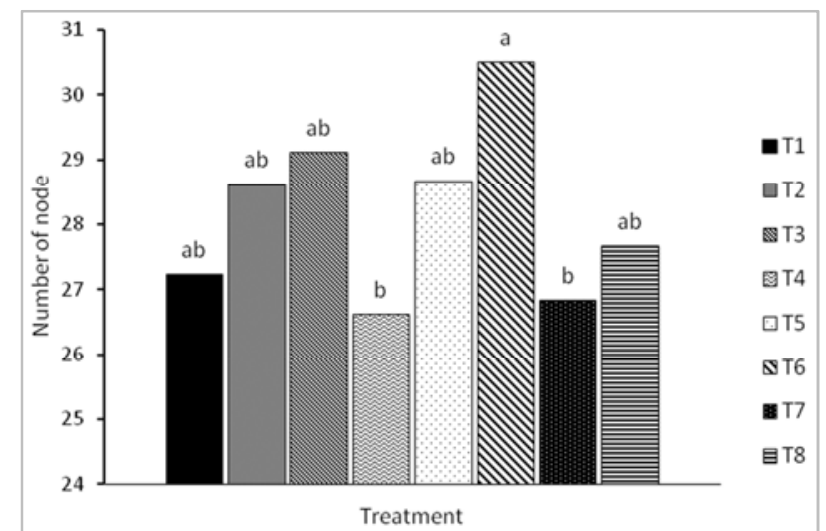

Figure 7. Effect of fertilizers, planting media and mycorrhizal inoculation treatments on number of rock melon node using Canopytechture structure under field condition. Means followed by the same letter in figure were not different at $p \leq 0.05$ by the least significant difference (LSD) test.

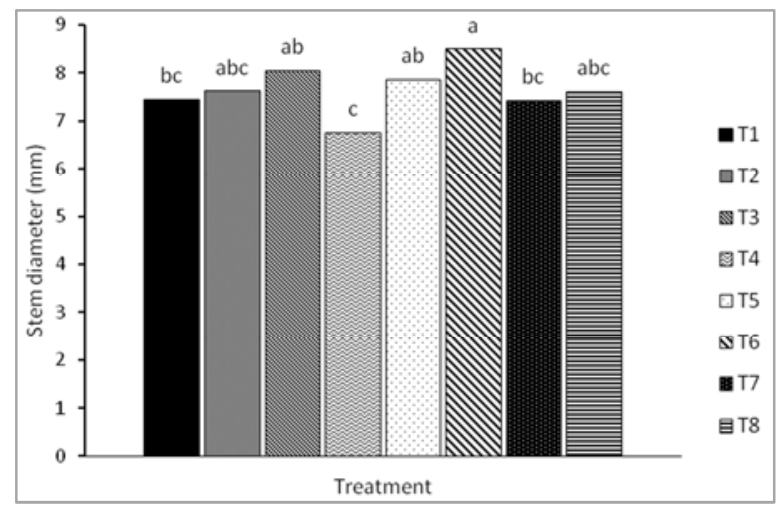

Figure 8. Effect of fertilizers, planting media and mycorrhizal inoculation treatments on stem diameter of rock melon using Canopytechture structure under field condition. Means followed by the same letter in figure were not different at $p \leq 0.05$ by the least significant difference (LSD) test.

\subsection{Stem Diameter}

At 76 DAT, stem diameter in T6 $(8.50 \mathrm{~mm})$ was higher than other treatments (Figure 8). Lowest stem diameter was recorded from T4 plants $(6.76 \mathrm{~mm})$. However, there were no significant differences between $\mathrm{T} 4, \mathrm{~T} 1, \mathrm{~T} 2, \mathrm{~T} 7$ and $\mathrm{T} 8$ plants which recorded $6.76,7.38,7.63,7.43$ and $7.63 \mathrm{~mm}$, respectively.

\subsection{Yield of Rock Melon}

Figure 9 shows the yield of rock melon at the final harvest (76 DAT). The yield of rock melon from T6 plants was maximum for all fruit parameters measured compared to other treatments. The selective parameters and their respective individual readings recorded are:

i Fresh fruit weight - T1 $(908.60 \mathrm{~g})$ : T2 (1049.55 g): T3 $(1221.68 \mathrm{~g}):$ T4 $(717.01 \mathrm{~g}):$ T5 $(1200.31 \mathrm{~g}):$ T6 $(1350.00 \mathrm{~g}):$ T7 $(871.70 \mathrm{~g}):$ T8 $(1007.84 \mathrm{~g})$

ii Fruit length - T1 $(152.22 \mathrm{~mm}): \mathrm{T} 2(155.75 \mathrm{~mm}): \mathrm{T} 3$ $(160.34 \mathrm{~mm}):$ T4 $(140.22 \mathrm{~mm}):$ T5 $(159.12 \mathrm{~mm}):$ T6 (168.25 mm): T7 (151.34 mm): T8 (155.34 mm)

iii Fruit diameter - T1 $(146.46 \mathrm{~mm})$ : T2 $(150.45 \mathrm{~mm})$ : T3 $(154.62 \mathrm{~mm}): \mathrm{T} 4(137.89 \mathrm{~mm}): \mathrm{T} 5(154.12 \mathrm{~mm}): \mathrm{T} 6$ (156.45 mm): T7 (146.12 mm): T8 (150.18 mm)

iv Rind thickness - T1 $(5.34 \mathrm{~mm})$ : T2 $(6.39 \mathrm{~mm})$ : T3 $(8.70 \mathrm{~mm}): \mathrm{T} 4(4.26 \mathrm{~mm}): \mathrm{T} 5(6.89 \mathrm{~mm}): \mathrm{T} 6(9.89$ $\mathrm{mm})$ : T7 (5.17 mm): T8 (5.72 mm)

v Flesh thickness - T1 $(19.29 \mathrm{~mm})$ : T2 $(20.21 \mathrm{~mm}): \mathrm{T} 3$ $(21.67 \mathrm{~mm}):$ T4 $(12.84 \mathrm{~mm}):$ T5 $(20.42 \mathrm{~mm}):$ T6 (23.78 mm): T7 (19.06 mm): T8 (19.60 mm)

Total soluble solids - T1 (12.06 $\left.{ }^{\circ} \mathrm{Brix}\right)$ : T2 (13.60 $\left.{ }^{\circ} \mathrm{Brix}\right)$ : T3 (14.05 ${ }^{\circ}$ Brix): T4 (10.17 $\left.{ }^{\circ} \mathrm{Brix}\right)$ : T5 (14.00 $\left.{ }^{\circ} \mathrm{Brix}\right)$ : T6 (14.25 ${ }^{\circ}$ Brix): $\mathrm{T} 7$ (10.32 $\left.{ }^{\circ} \mathrm{Brix}\right)$ : $\mathrm{T} 8$ (12.10 $\left.{ }^{\circ} \mathrm{Brix}\right)$

Lowest harvest for all parameters above was from $\mathrm{T} 4$ plants, while T6 was greatest. At 76 DAT, fresh weight, fruit length, fruit diameter, rind thickness, flesh thickness and total soluble solids of both T6 plants were maximum at $1350 \mathrm{~g}$ (Figure 9a), $168.25 \mathrm{~mm}$ (Figure 9b), $156.45 \mathrm{~mm}$ (Figure 9c), $9.89 \mathrm{~mm}$ (Figure 9d), $23.78 \mathrm{~mm}$ (Figure 9e) and $14.25^{\circ}$ Brix (Figure 9f), respectively. Flesh thickness of $23.78 \mathrm{~mm}$ from T6 plants was highest and significant compared to T1, T2, T4, T5, T7 and T8 plants (Figure 9e). The total soluble solid was maximum for T6 (14.25 ${ }^{\circ}$ Brix $)$ and it's reading was not significantly different to other treatments except T4 $\left(10.17{ }^{\circ}\right.$ Brix) (Figure 9f).

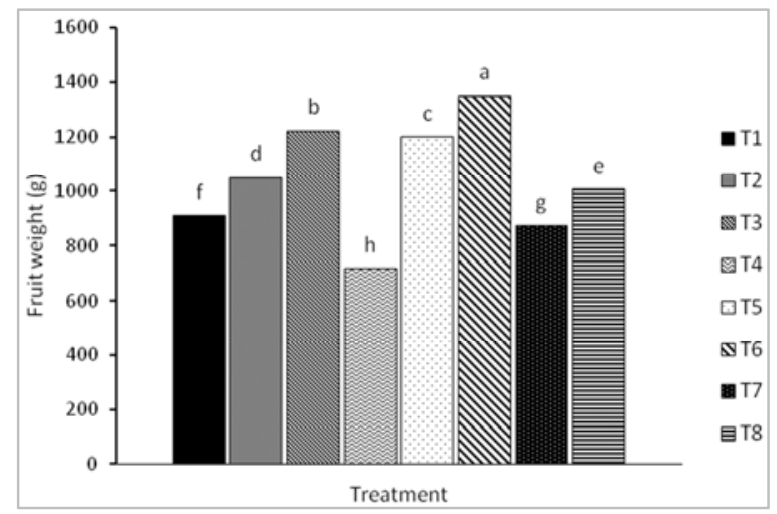

(a) Fresh fruit weight 


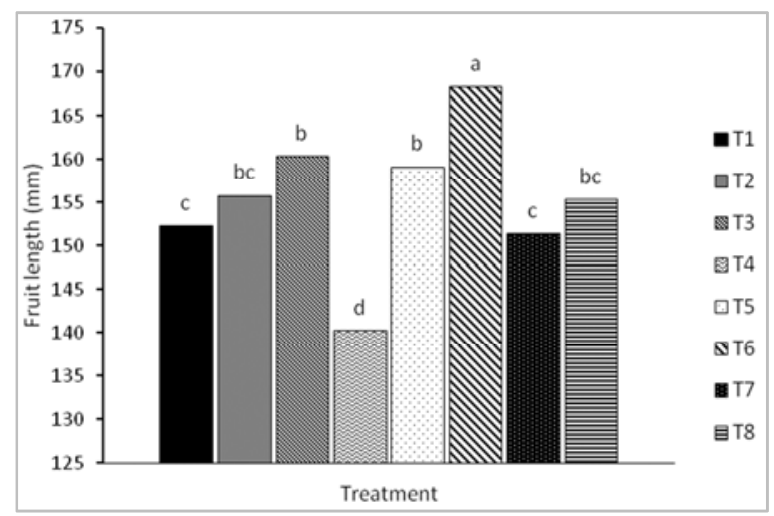

(b) Fruit length

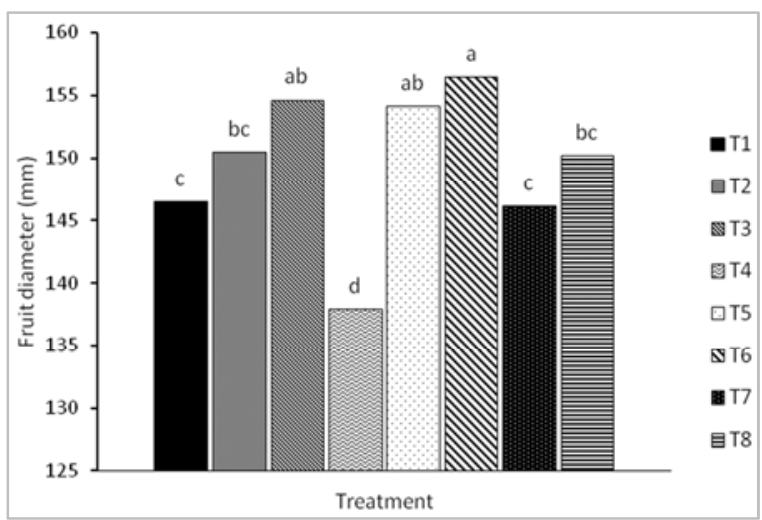

(c) Fruit diameter

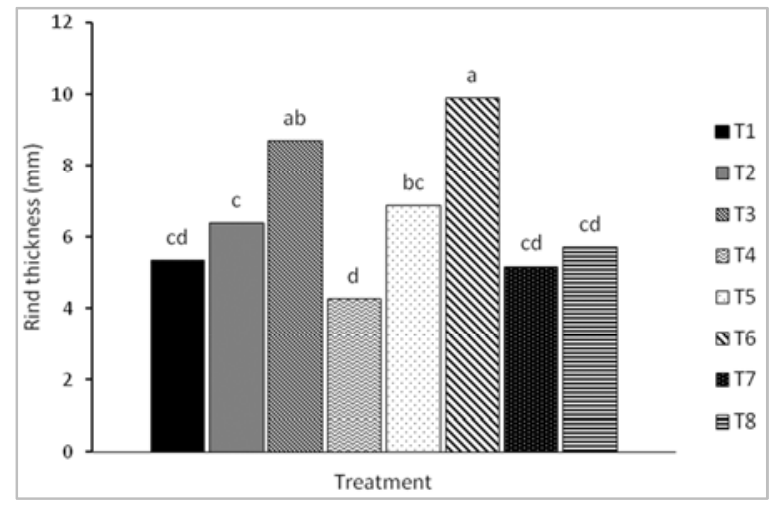

(d) Rind thickness

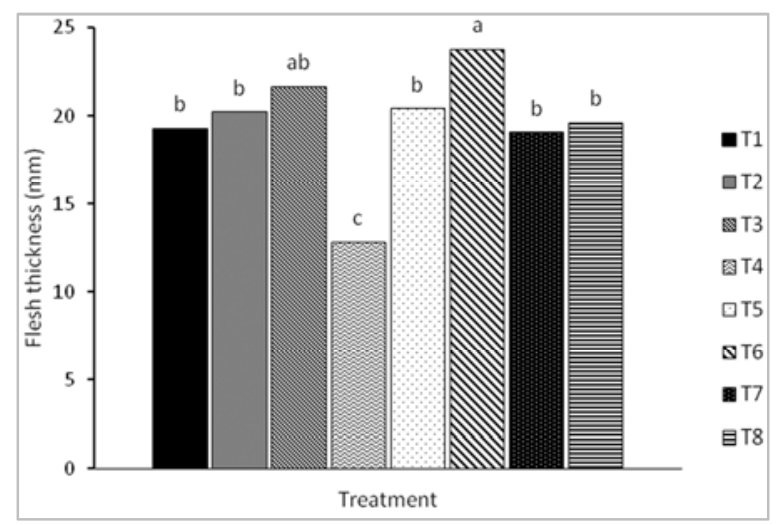

(e) Flesh thickness

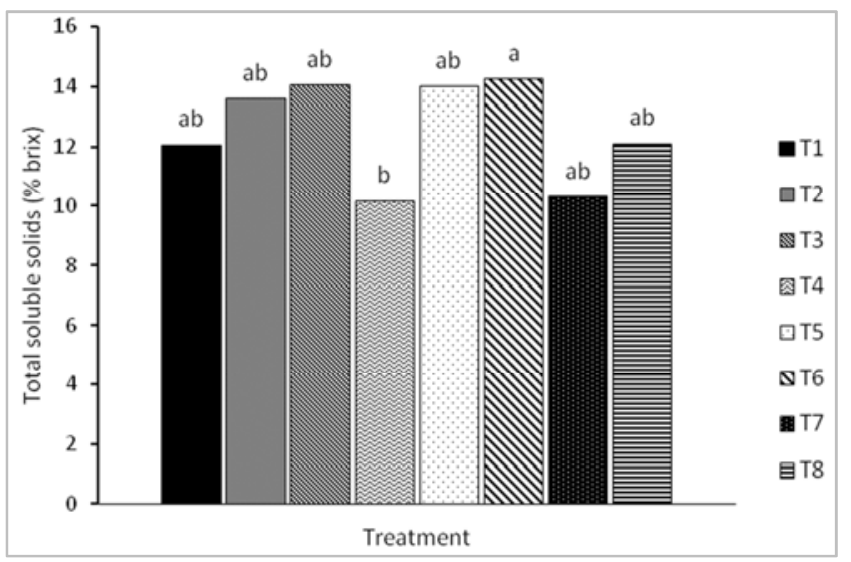

(f) Total soluble solids

Figure 9. Effect of fertilizers, planting medium and mycorrhizal inoculation treatment of rock melon using Canopytechture structure under field condition on (a) Fruit fresh weight (g); (b) Fruit length (g); (c) Fruit diameter (mm); (d) Rind thickness (mm); (e) Flesh thickness ( $\mathrm{mm}$ ) and (f) Total soluble solids ( ${ }^{B}$ Brix) of rock melon at harvest stage (76 DAT). Means followed by the same letter in each sub figure were not different at $p \leq 0.05$ by the least significant difference $(L S D)$ test. $(T 1=$ Medium A - Mycorrhiza + Inorganic fertilizer, $T 2=$ Medium $A+$ Mycorrhiza + Organic fertilizer, $T 3=$ Medium A + Mycorrhiza + Inorganic fertilizer, T4 = Medium A - Mycorrhiza + Organic fertilizer, $T 5=$ Medium $B+$ Mycorrhiza + Organic fertilizer, T6 $=$ Medium $B+$ Mycorrhiza + Inorganic fertilizer, $T 7=$ Medium $B-$ Mycorrhiza + Organic fertilizer and $T 8=$ Medium $B-$ Mycorrhiza + Inorganic fertilizer). The F ( $\mathrm{Pr}>\mathrm{F})$ for $(a)$; (b); (c); (d); (e) and (f) were $11529.5(<0.0001) ; 14.85(<0.0001) ; 8.36(<0.0001) ; 7.66(<0.0001) ; 11.39$ $(<0.0001)$ and $1.29(0.2579)$ respectively.

\subsection{Effect of Type Fertilizers, Planting Medium and Mycorrhizal Application on Plant Growth}

Fertilizers are essential for crop production since plants need them for growth, tissue expansion and yield production. Growth and yield of rock melon was significantly affected by the nutrient system. Plants receiving T6, (Peat moss + Perlite + Vermiculite + Top soil + Mycorrhiza + Inorganic fertilizer) grew better at both vegetative and reproductive stages. At 76 DAT the number of leaves, stem diameter, fruit weight, fruit length, fruit diameter, rind and flesh thickness of T6 plants $(31.39,8.5 \mathrm{~mm}, 1350 \mathrm{~g}, 168.25 \mathrm{~mm}, 156.45 \mathrm{~mm}, 9.89 \mathrm{~mm}$, $23.78 \mathrm{~mm}$ ) were $12 \%, 12 \%, 33 \%, 10 \%, 6 \%, 46 \%, 19 \%$ higher than that of control plants in T1, $(27.72,7.45 \mathrm{~mm}$, $908.6 \mathrm{~g}, 152.22 \mathrm{~mm}, 146.46 \mathrm{~mm}, 5.34 \mathrm{~mm}, 19.29 \mathrm{~mm})$ and $15 \%, 20 \%, 47 \%, 17 \%, 12 \%, 57 \%, 46 \%$ higher than that of T4 plants $(26.83,6.76 \mathrm{~mm}, 717.0 \mathrm{~g}, 140.22 \mathrm{~mm}, 137.89 \mathrm{~mm}$, $4.26 \mathrm{~mm}, 12.84 \mathrm{~mm}$ ). The superior significance in all the parameters above are strongly supported by combination of planting medium (peat moss, perlite, vermiculite, top soil), mycorrhizal and inorganic of T6 plants.

However, results showed that almost all plants which were treated with mycorrhizal inoculations significantly had increased number of leaf, stem diameter, fruit weight, fruit length, fruit diameter, rind and flesh thickness and flesh thickness. Cagras [13] found that mycorrhizal inoculation of cucumber plants significantly increased leaf and shoot fresh and dry weight, root biomass and leaf area index. Lee and George [14] showed that mycorrhizal hyphae of G. mosseae 
had a significant contribution in the uptake of $\mathrm{P}, \mathrm{Zn}$ and $\mathrm{Cu}$ by inoculated cucumber plants resulting in a increased concentration of those nutrients in the plant shoots. Wang [15] also showed an increased macro nutrient element uptake in inoculated cucumber plants.

Overall, T6 plants showed superior results as compared to other treatments in terms of weight, rind and flesh thickness of fruit. Inorganic fertilizer application enhances plant growth and yield because it is absorbed quickly by soil and plants. Therefore, farmers apply maximum amounts of inorganic fertilizers to their crops to achieve higher yield. As a result, excess inorganic fertilizers leach into the ground water and polluting it. To avoid this situation, a combination of inorganic fertilizer with biological ingredients is better to use in crop cultivation. Mycorrhiza is a type of organic fertilizer or bio fertilizer that creates mutual symbiosis between mycorrhizal fungi and higher plants. Mycorrhiza improves crop yield and increases the use of inorganic fertilizer by forming a bridge between the roots and the soil. It is indirectly enhancing the structure of the soil (planting medium) and improves air and water infiltration.

\section{Conclusions}

In conclusion, different types of fertilizers, planting media and mycorrhiza strongly affect vegetative and reproductive growth of melon. Results obtained from the current study indicates that both vegetative and reproductive growth of Cucumis melo plants were strongly affected by type of fertilizer, planting media and mycorrhiza applied. The overall rock melon plant yield changed and improved, although mycorrhizal inoculation was always beneficial for plant growth. The effects of the isolates were consistently the best; and gave good results, establishing good root colonization and increased rock melon yield, and could be integrated in rock melon production as an ecologically sound practice. We can conclude that rock melon plants readily establish the arbuscular mycorrhiza symbiosis with different planting medium types. The fungal species, planting media and fertilizer types increase plant yield and nutrient uptake, while inoculation always resulted in better plant growth. Seedling inoculation significantly increased rock melon survival at transplanting. The effects of other factors involved in plant growth such as weather conditions, seedling production, standardization of the inoculate, and crop management techniques need to be further studied in order to effectively integrate the mycorrhiza technology in horticulture production.

\section{Acknowledgements}

The authors wish to express their gratitude to MARDI for providing the funding for this study. Special thanks to Mr. Helmey Othman, Mr. Khairil Abas and Mr. Abd Aziz Mat Rasul for their technical assistance.

\section{References}

[1] Hooker, J. E. and Black, K. E. 1995. Arbuscular mycorrhizal fungi as components of sustainable soil-plant systems. Crit Rev Biotechnol., 15, 201-212.

[2] Hamdan, M. N. 2015. Effect of partial root drying, regulated deficit irrigation and mycorrhiza on growth performance and physiological responses of rock melon (Cucumis melo Linn). MSc. Thesis., University Putra Malaysia, 2015. 113 pp.

[3] Ortas, I., Kaya, Z. and Cakmak, I. 2001. Influence of VAmycorrhiza inoculation on growth of maize and green pepper plants in phosphorus and zinc deficient soils. In: Plant nutrition- Food security and sustainability of agroecosystems (Horst, W. J. et al., eds). Kluwer Acad Publ., Dordrecht. pp. 632-633.

[4] Al-Karaki, G. N. 2006. Nursery inoculation of tomato with arbuscular mycorrhizal fungi and subsequent performance under irrigation with saline water. Scientia Horticulture., 109, 1-7.

[5] Plenchette, C., Clermont-Dauphin, C., Meynard, J. M. and Fortin, J. A. 2005. Managing arbuscular mycorrhizal fungi in cropping systems. Can J Plant Sci., 85(1), 31-40.

[6] Estaun, V., Camprubi, A. and Joner E. J. 2002. Selecting arbuscular mycorrhizal fungi for field application. In: Mycorrhizal technology in agriculture (Gianinazzi, S., Schuepp, H., Barea, J. M., Haselwandter, K. and eds.). Birkhauser Verlag, Berlin. pp. 249-259.

[7] Ortas, I. 2008. Field trials on mycorrhizal inoculation in the eastern mediterranean horticultural region. In: Mycorrhiza works (F. Feldmann, Y. Kapulnık, J. Baar and eds). Hannover, Germany. pp 56-77.

[8] Kubota, M., Mcgonigle, T. P. and Hyakumachi, M. 2005. Cooccurrence of Arumand Paris-type morphologies of arbuscular mycorrhizae in cucumber and tomato. Mycorrhiza 15, 73-77.

[9] Sainz, M. J., Taboada-Castro, M. T. and Vilarino, A. 1998. Growth, mineral nutrition and mycorrhizal colonization of red clover and cucumber plants grown in a soil amended with composted urban wastes. Plant Soil., 205, 85-92.

[10] Charron, G., Furlan, V., Bernier-Cardou, M. and Doyon, G. 2001. Response of onion plants to arbuscular mycorrhizae. 2. Effects of inoculum method and phosphorus fertilization on biomass and bulp firmness. Mycorrhiza 11, 187-197.

[11] Ortas, I. 2003. Effect of selected mycorrhizal inoculation on phosphorus sustainability in sterile and no-sterile soils in the Harran Plain in South Anatolia. J Plant Nutr., 26(1), 1-17.

[12] Statistical Analysis System (SAS Institute). 2011. SAS software, release 6.08. 6th ed., Inc Cary, NC, USA.

[13] Cagras, S., Sari, N. and Ortas, I. 2000. The effects of vesiculararbuscular mycorrhizae on the plant growth and nutrient uptake of cucumber. Turk J Agric Forest., 24, 571-578.

[14] Lee, Y. J. and George, E. 2005. Contribution of mycorrhizal hyphae to the uptake of metal cations by cucumber plants at two levels of phosphorus supply. Plant Soil., 278(1-2), 361-370.

[15] Wang, C., Li, X., Zhou, J., Wang, G. and Dong, Y. 2008. Effects of arbuscular mycorrhizal fungi on growth and yield of cucumber plants. Comm Soil Sci Plant Anal., 39, 499-509. 